\title{
PENGGUNAAN METODE MARMET UNTUK MELANCARKAN PENGELUARAN AIR SUSU IBU (ASI) PADA IBU MENYUSUI 0-6 BULAN DI RUMAH SAKIT IBU DAN ANAK ERIA BUNDA PEKANBARU
}

\author{
Wiwik Norlita, Tri Siwi KN \\ Fakultas MIPA dan Kesehatan, Universitas Muhammadiyah Riau \\ Jln. Tuanku Tambusai Ujung No. 1 Pekanbaru 28285 \\ e-mail: trisiwinaning@gmail.com
}

\begin{abstract}
ABSTRAK
Metode marmet merupakan salah satu cara mengeluarkan ASI dengan pijitan dengan menggunakan dua jari. Dengan metode marmet ASI bisa keluar dengan lancar. Mengeluarkan ASI menggunakan metode marmet membutuhkan waktu masing-masing payudara sekitar 15 menit . Metode marmet banyak digunakan sebagai salah satu upaya yang dapat dilakukan untuk meningkatkan cakupan ASI eksklusif pada bayi 0-6 bulan serta peningkatan pengeluaran ASI. Tujuan penelitian ini adalah untuk mengetahui bagaimana metode marmet terhadap kelancaran pengeluaran ASI pada ibu di Rumah Sakit Ibu dan Anak Eria Bunda Pekanbaru. Jenis penelitian menggunakan metode quasi experiment dengan teknik pengambilan sampel accidental sampling yang berjumlah 20 responden. Pengumpulan data dilakukan dengan observasi serta pengukuran jumlah ASI. Analisis data menggunakan uji paired T Test.. Hasil Penelitian menunjukkan pemberian teknik marmet efektif terhadap kelancaran pengeluaran ASI pada ibu dengan $P$ value $=0,00$. Diharapkan kepada ibu dapat secara kontinyu menggunakan metode marmet untuk mempertahankan kelancaran pengeluaran ASI.
\end{abstract}

Kata kunci: Metode Marmet, pengeluaran ASI.

\section{PENDAHULUAN}

Metode marmet merupakan suatu cara yang digunakan untuk mengeluarkan ASI. Teknik ini memberikan efek relaks dan juga mengaktifkan kembali reflek keluarnya air susu/ milk ejection refleks (MER) sehingga air susu mulai menetes. Dengan diaktifkannya MER maka ASI akan sering menyemprot keluar dengan sendirinya Metode marmet dapat membantu kelancaran pengeluaran ASI secara alamiah untuk memenuhi kebutuhan nutrisi bayi. (Martha \& William, 2007).

Permasalahan tidak lancarnya proses keluarnya ASI yang menjadi salah satu penyebab seseorang tidak dapat menyusui bayinya sehingga proses menyusui terganggu. Oleh karena itu diperlukan diadakannya pendekatan pada masyarakat untuk dapat mengubah kebiasan buruk memberikan makanan pendamping ASI sebelum bayi berusia 6 bulan dan pengenalan berbagai metode yang dapat membantu ibu menyusui untuk memperlancar pengeluaran ASI salah satunya adalah menggunakan metode marmet (Arisman, 2013).
Penggunaan metode marmet merupakan salah satu upaya yang dilakukan dalam meningkatkan cakupan ASI eksklusif pada bayi 0-6 bulan serta peningkatan pengeluaran ASI.. Cara ini sering disebut juga dengan back to nature karena caranya sederhana dan tidak membutuhkan biaya serta efektif merangsang payudara untuk memproduksi lebih banyak ASI (Nurdiansyah, 2011).

\section{METODOLOGI PENELITIAN}

Jenis Penelitian yang digunakan adalah kuasi eksperimen dengan menggunakan dua kelompok control dan kelompok intervensi berjumlah 20 responden. Analisis data menggunakan uji paired $\mathrm{t}$ test.

\section{HASIL DAN PEMBAHASAN}

Hasil penelitian yang dilakukan tentang metode marmet untuk melancarkan pengeluaran ASI pada ibu menyusui 0-6 bulan di RSIA Eria Bunda dengan jumlah responden 20 orang responden adalah sebagai berikut: 
1. Analisa Univariat

Tabel 3.1

Distribusi Frekuensi Kelompok Responden pada penelitian penggunaan metode marmet untuk melancarkan pengeluaran ASI pada Ibu Menyusui 0-6 Bulan di Rumah Sakit Ibu dan Anak Eria Bunda Pekanbaru Tahun 2017

\begin{tabular}{cccc}
\hline No & Kriteria Responden & $\begin{array}{c}\text { Frekuensi } \\
(\mathbf{f})\end{array}$ & $\begin{array}{c}\text { Persentase } \\
(\mathbf{\%})\end{array}$ \\
\hline 1 & Kelompok Kontrol & 10 & 50,0 \\
2 & Kelompok Intervensi & 10 & 50,0 \\
\hline Total & $\mathbf{2 0}$ & $\mathbf{1 0 0}$ \\
\hline
\end{tabular}

Berdasarkan tabel 3.1 dapat dilihat bahwa kriteria responden kelompok kontrol yaitu sebanyak $10(50,0 \%)$ responden, dan kelompok intervensi sebanyak $10(50,0 \%)$ responden. Hal

\section{Tabel 3.2}

ini menunjukkan kepada 20 responden atas permintaan peneliti sendiri dan akan menjadi dua kelompok.

Distribusi Frekuensi Umur responden pada penelitian penggunaan metode marmet untuk melancarkan pengeluaran ASI pada Ibu Menyusui 0-6 Bulan di Rumah Sakit Ibu dan Anak Eria

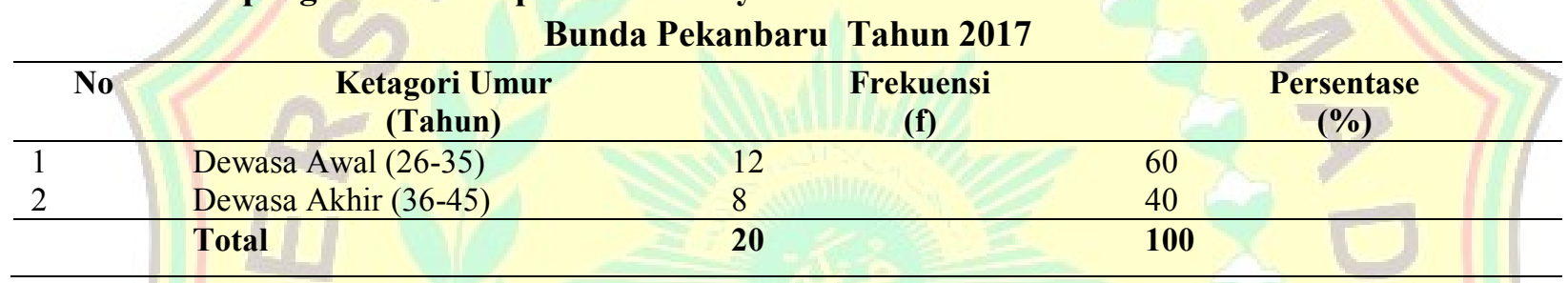

Berdasarkan tabel diatas menunjukkan mayoritas responden pada kategori usua dewasa awal berjumlah $60 \%$.

2. Analisa Bivariat

Tabel 3.3

Hasil Uji Statistik pengeluaran ASI hari kesatu pada penelitian penggunaan metode marmet untuk melancarkan pengeluaran ASI pada Ibu Menyusui 0-6 Bulan di Rumah Sakit Ibu dan Anak Eria Bunda Pekanbaru Tahun 2017

\begin{tabular}{|c|c|c|c|c|c|c|c|}
\hline Subjek & Metode & $\mathbf{N}$ & Mean & SD & $\mathbf{T}$ & Df & $\begin{array}{c}\text { Sig. (2- } \\
\text { tailed) }\end{array}$ \\
\hline \multirow[b]{2}{*}{ Pengeluaran ASI } & $\begin{array}{l}\text { Teknik } \\
\text { Marmet }\end{array}$ & 10 & 52,0 & 13,1 & \multirow[b]{2}{*}{2,977} & \multirow[b]{2}{*}{18} & \multirow[b]{2}{*}{0.008} \\
\hline & $\begin{array}{l}\text { Tanpa } \\
\text { Teknik } \\
\text { Marmet }\end{array}$ & 10 & 36,0 & 10,7 & & & \\
\hline
\end{tabular}

Dari tabel diatas diketahui nilai $\mathrm{t}_{\text {hitungsebesar }}$ 2,977 dengan $\mathrm{P}_{\text {value }}$ (Sig.) sebesar 0,008. Sedangkan nilai $\mathrm{t}$ tablepada signifikansi 5\%(2tailed) dengan df 18 sebesar 2,100. Dengan demikian diketahui $t$ hitung $(2,977)>t$ tabel $(2,100)$ hal ini terdapat perbedaan yang signifikan antara penggunaan teknik marmet dan tanpa penggunaan teknik marmet dalam pengeluaran ASI dibuktikan dengan dengan nila $\mathrm{P}_{\text {value }}(0,008)$ $<0,05$ dalam hal ini penggunaan teknik marmet lebih efektif melancarkan pengeluaran ASI. 
Tabel 3.4

Hasil Uji Statistik pengeluaran ASI pada hari ketujuh pada penelitian penggunaan metode marmet untuk melancarkan pengeluaran ASI pada Ibu Menyusui 0-6 Bulan di Rumah Sakit Ibu dan Anak Eria Bunda Pekanbaru Tahun 2017

\begin{tabular}{|c|c|c|c|c|c|c|c|}
\hline Subjek & Metode & $\mathbf{N}$ & Mean & SD & $\mathbf{T}$ & Df & $\begin{array}{l}\text { Sig. (2- } \\
\text { tailed) }\end{array}$ \\
\hline \multirow[b]{2}{*}{ Pengeluaran ASI } & $\begin{array}{l}\text { Teknik } \\
\text { Marmet }\end{array}$ & 10 & 71,00 & 11,25 & \multirow[b]{2}{*}{9,54} & \multirow[b]{2}{*}{18} & \multirow[b]{2}{*}{0.000} \\
\hline & $\begin{array}{c}\text { Tanpa } \\
\text { Teknik } \\
\text { Marmet }\end{array}$ & 10 & 31,00 & 6,99 & & & \\
\hline
\end{tabular}

Dari tabel diatas diketahui nilai $\mathrm{t}_{\text {hitungsebesar }}$ 9,54 dengan $P_{\text {value }}$ (Sig.) sebesar 0,000. Sedangkan nilai $\mathrm{t}_{\text {table }}$ pada signifikansi $5 \%$ (2-tailed) dengan df 18 sebesar 2,100. Dengan demikian diketahui $t_{\text {hitung }}(9,54)>t_{\text {tabel }}(2,100)$ hal ini berarti terdapat perbedaan yang signifakan antara penggunaan teknik marmet dan tanpa penggunaan teknik marmet dibuktikan dengan nilai $\mathrm{P}_{\text {value }}(0,000)<$ 0,05

Hal ini sejalan dengan penelitian yang dilakukan oleh Andriyani (2014), dengan judul Metode memperbanyak produksi ASI pada ibu post partum dengan tehnik marmet dan breast care, didapatkan $p$-value sebesar 0,047 maka $H o$ ditolak dan $\mathrm{Ha}$ diterima, sehingga secara statistik pada penelitian ini ada beda teknik marmet dengan massa payudara dalam mempengaruhi kelancaran ASI.

Penelitian yang dilakukan oleh Widiastuti tahun 2015 dengan judul penelitian Pengaruh Teknik Marmet dengan Masase Payudara pada Ibu Nifas Tiga Hari Post Partum Terhadap Kelancaran ASI juga memperoleh hasil yang sama . Rata-rata produksi ASI sesudah diberikan teknik marmet sebesar 74,81 mg, hal ini termasuk lebih dari normal sehingga dapat diketahui bahwa sebagian besar ibu mengalami produksi ASInya lancar. Berdasarkan uji statistisk menggunakan Independent T-Test, didapatkan bahwa p 0,000. Berdasarkan hasil tersebut diketahui $\mathrm{p}<0.05$. yang

Penelitian Rani (2014), yang berjudul metode memperbanyak ASI Pada Ibu Post Sectio Caesarea dengan teknik marmet dan breast care Di RSUD Karanganyar juga menunjukkan hasil pada kelompok intervensi terdapat perbedaan produksi ASI sebelum dan sesudah diberikan teknik marmet ( $\mathrm{p}$ value $0.000<0.05$, sedangkan pada kelompok kontrol ada perbedaan sebelum dan sesudah diberikan breast care ( $p$ value) 0.000 $<0.05$.

Ningrum (2017), menyatakan bahwa produksi ASI dan kelancaran pengeluaran ASI memerlukan rangsangan pada otot-otot payudara agar kelenjar payudara bekerja dengan lebih efektif, sehingga otot-otot akan berkontraksi lebih baik dan kontraksi yang baik ini diperlukan dalam proses laktasi. Rangsangan pada otot-otot payudara ini dapat dilakukan dengan pemijatan atau masase payudara salah satunya melalui pemberian teknik marmet.

Dengan demikian peneliti berpendapat bahwa metode marmet sangat perlu disosialisasikan kepada para komunitas ibu menyusui karena metode ini stidak memerlukan biaya, aman dan sangat efektif untuk melancarkan pengeluaran ASI sehingga kebutuhan ASI pada bayi dapat terpenuhi secara maksimal.

\section{KESIMPULAN}

Hasil penelitian yang telah dilakukan pada bulan Agustus 2017 pada ibu yang berkunjung ke RSIA Eria Bunda menunjukkan adanya hubungan yang bermakna pemberian teknik marmet efektif terhadap kelancaran pengeluaran ASI pada ibu dengan $P$ value $=0,00$. Diharapkan kepada ibu dapat secara kontinyu menggunakan metode marmet untuk mempertahankan kelancaran pengeluaran ASI. 


\section{DAFTAR PUSTAKA}

Widiastuti, A. (2015). Pengaruh Teknik Marmet terhadap Kelancaran Air Susu

Ibu dan Kenaikan Berat Badan Bayi. Jurnal Keperawatan

Andriyani, A. (2014). Metode memperbanyak produksi asi pada ibu post sectio

Caesarea dengan tehnik marmet dan breast care Di rsud karanganyar. Jurnal keperawatan

Arisman (2013). Target Pencapaian ASI. Jakarta: EGC

Astutik, R. (2014). Payudara Dan Laktasi. Jakarta: Salemba Medika

Aziz, A. (2011). Konsep Efektifitas. Jakarta: Erlangga

Badriul (2008). Buku Ajar Keperawatan Maternitas edisi 4. Jakarta: EGC.

Bobak, dkk. (2003). Buku Ajar Keperawatan Maternitas, Edisi 4, Jakarta: EGC.

Evariny (2013). Metode Teknik Marmet. Penerbit: Soetomo Putra. Bandung

Hamilton, P. (2011). Dasar-dasar Keperawatan Maternitas. Edisi 6 Jakarta: EGC.

Hidayat (2009). Buku Ajar Makanan dan Nutrisi Bayi. Edisi 2

IDAI. (2013). Kendala Pemberian ASI Eksklusif. Jurnal Penelitian

Khairuniyah (2015). Pengertian ASI. Jakarta: Selemba

Khusul, H. (2016). Pengaruh teknik marmet terhadap produksi asi pada ibu post partum di rumah sakit pku Muhammadiyah gamping. Jurnal Penelitian
Martha \& William, (2007). Teknik Marmet. Penerbit Yuli. Yogyakarta

Masadah (2015). Teknik Meningkatkan Dan Memperlancar Produksi Asi Pada Ibu Post Sectio Caesaria. Jurnal Keperawatan

Ningrum, A. (2017). Pengaruh Pemberian Teknik Marmet Terhadap Produksi Asi Pada Ibu Post Partum Di Bpm Wilayah Kerja Puskesmas Sukorame Kota Kediri. Jurnal Penelitian

Nurdiansyah, N. (2011). Buku Pintar Ibu dan bayi. Jakarta: Kawah Media

Notoatmodjo, S. (2010). Metodologi Penelitian Kesehatan. Jakarta: Rineke Cipta

Purwanti(2013). Konsep Penerapan ASI Eksklusif. Bandung: Cendekia

Profil Kesehatan Indonesia. (2014). Cakupan ASI. Jakarta. http://www.depkes. go.id. di akses tanggal 28 Desember 2016.

Rahayu, R. (2014). Metode memperbanyak produksi asi pada ibu post sectio Caesarea dengan tehnik marmet dan breast care Di rsud karanganyar. Jurnal penelitian

Roesli, U. (2000). Buku Pintar ASI Eksklusif. Yogyakarta. Diva Press

Rohani. (2011). Konsep Dasar Persalinan. Maternitas. Penerbit Raden Roro. Bandung

Wong (2011). Panduan dan Konsep Dasar Bayi. Bumi Aksara. Jakarta

Yuliarti, N. (2010). ASI, Makanan Terbaik untuk Kesehatan, Kecerdasan dan Kelincahan Si Kecil. Penerbit Andi. Yogyakarta 